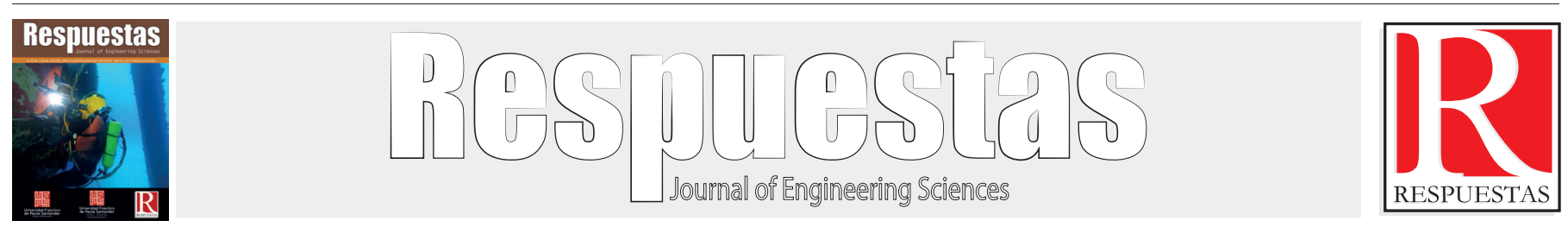

Original Article

https://doi.org/10.22463/0122820X.2403

\title{
Analysis of the relationship between the water retention curve, particle size and pore size distribution in the characterization of a collapsible porous clay
}

\author{
Análisis de la relación entre la curva de retención de agua, distribución de tamaño de partículas y de poros \\ en la caracterización de una arcilla porosa colapsable \\ María Camila Olarte ${ }^{1}$ Juan Carlos Ruge ${ }^{2 *}$ \\ ${ }^{1}$ Ingeniera Civil, u1102789@unimilitaredu.co, Universidad Militar Nueva Granada, Think Tank en Imagenología y Modelación Numérica de Geomateriales., Bogotá, Colombia. \\ https://orcid.org/0000-0003-0253-5618 \\ 2*PhD. en Geotecnia, juan.ruge@unimilitar.edu.co, Universidad Militar Nueva Granada, Grupo de Investigación en Geotecnia. Bogotá, Colombia. https://orcid.org/0000-0002- \\ $8831-0315$
}

How to cite: M.C. Olarte, J.C. Ruge, "Analysis of the relationship between the water retention curve, particle size and pore size distribution in the characterization of a collapsible porous clay". Respuestas, vol. 25, no. 1, pp. 33-43, 2020.

Received on July 9, 2019; Approved on December 5, 2019

\begin{tabular}{ll}
\hline & ABSTRACT \\
\hline Keywords: & $\begin{array}{l}\text { In highly porous soils with a susceptibility to collapse, there are points of volumetric variability, due to the present } \\
\text { heterogeneity, regarding the diameters of the poral throat. The predominance of a pore size is closely related to certain } \\
\text { values of the Water Retention Curve (WRC). However, to date, a possible correlation with particle size distribution } \\
\text { (PaSD), obtained using modern, highly reliable gravitational sedimentation methods, has not been studied. The porous } \\
\text { Particle size distribution, } \\
\text { Pore size distribution, }\end{array}$ - $\begin{array}{l}\text { Subsequently, it was analyzed by mercury intrusion porosimetry tests, to estimate the Pore Size Distribution (PSD); filter } \\
\text { paper and pressure plate method to obtain the water retention curve; as well as the method of integral measurement of } \\
\text { the pressure in the suspension (ISP), to obtain the fine grain size of the material. This article tries to present a proposal of } \\
\text { relationship between these parameters, with the aim of improving the understanding in the characterization of this type of } \\
\text { materials. The results showed that there is indeed a strong relationship between the particle size distributions, pore size } \\
\text { distribution and the water retention curve. Mainly, this is reflected in the geometric places corresponding to the air value } \\
\text { entries (AEV) of macropores and micropores. Which coincide with essential parameters of the behavior of the other curves } \\
\text { (PaSD and PSD). }\end{array}$
\end{tabular}

(PaSD and PSD).

\section{RESUMEN}

\section{Palabras clave:}

Curvas de retención de agua,

Distribución de tamaño de partículas, Distribución de tamaño de poros.
En suelos altamente porosos con susceptibilidad de colapso, existen puntos de variabilidad volumétrica, debido a la heterogeneidad presente, en cuanto a los diámetros de las gargantas porales. La predominancia de un tamaño de poro está estrechamente relacionada con ciertos valores de la curva de retención de agua (WRC). No obstante, a la fecha no se ha estudiado una posible correlación con la distribución del tamaño de partículas (PaSD), obtenida mediante métodos modernos de sedimentación gravitacional de alta confiabilidad. La arcilla porosa de origen laterítico bajo estudio, fue caracterizada mediante ensayos índice para conocer su comportamiento geotécnico básico. Posteriormente, fue analizada mediante ensayos de porosimetría por intrusión de mercurio para la estimación de la distribución del tamaño de poros PSD; método del papel filtro y placa de presión para la obtención de la curva de retención de agua; así como el método de medición integral de la presión en la suspensión (ISP), para obtener la granulometría fina del material. Este artículo pretende presentar una propuesta de relación entre estos parámetros, con el objetivo de mejorar el entendimiento en la caracterización de este tipo de materiales. Los resultados mostraron que efectivamente existe una relación fuerte entre las distribuciones de tamaño de partícula, poros y la curva de retención de agua. Principalmente, esto se ve reflejado en los lugares geométricos correspondientes a las entradas de valor de aire (AEV) de macroporos y microporos. Las cuales coinciden con parámetros esenciales del comportamiento de las demás curvas (PaSD y PSD).

*Corresponding author.

E-mail Address:juan.ruge@unimilitar.edu.co (Juan Carlos Ruge) 


\section{Introduction}

Within the current state of the art of the subject being addressed it is widely known that there is a close relationship between the pore size distribution (PSD), the water retention curve (WRC) and the particle size distribution (PaSD). The first, also known as porosimetry, is widely used to conglomerate the characteristics related to the porosity of a material and to understand the physical variations that directly affect its behavior and mechanical response. In ceramic materials, porosity and impermeability are due to the combination of free silica, aluminum alkalis and aluminum silicates [1]. According to [2], water retention curves express the relationship between the suction of unsaturated soils and the water content to determine the properties of shear strength, permeability and volumetric changes [3]. As for PaSD, it is the determination of the range of particle size present in a soil. In order to analyze the indirect dependence between $\mathrm{PaSD}$, PSD and WRC, the internal relations of each one of them are inferred, since the proper understanding and interpretation of the WRC is important for a correct characterization of the soil, since it can collaterally give an archetype of the behavior and mechanical response of unsaturated soils [4] - [6].

One of the most common pathologies within soil mechanics is collapse, present in fine granulometry, and caused by variations in humidity with considerable stress loads, thus originating representative settlements [7]. There are various experimental methods, both traditional and modern, that attempt to contribute to the investigation of the interrelationship of these parameters, based on constitutive models that seek to simulate the possible stress trajectories that a soil may experience.

The integral suspension method (ISP), is based on the pressure of the suspension at a selected depth, in simpler words, it is a general measure of all the particles in suspension above a checking depth. It should be understood, that the general objective of this method is to calculate the particle size of a fine soil by gravitational settlement analysis based on Stokes' law (1850). Based on this constitutive law, the measurement method of the integral sedimentation system does not make use of corrective soil measurements with function transfer. In a retrospective analysis, its predecessor, the hydrometer, has its main basis in determining the density of an aqueous soil suspension [8]. The pipette method is highly used in rudimentary experimental and early research work, since it is mainly based on measuring the percentage by weight of each particle size in suspension, assuming constant specific gravity conditions [9].

Several methodologies have been developed to determine the porous structure of a soil, which differ according to the number of parameters involved that can indirectly influence the volume-pressure curve. Due to the very nature and the multivariate profiles that porous materials can acquire [10], whether extruded, sheets or monoliths, special emphasis should be placed on fine particle size, which is considered a primary realistic factor in the research.

Choosing the most appropriate method that can produce the least dispersion of data when extrapolated to an overall behaviour, depends directly on the application of the porous soil, as well as its chemical and physical nature. Mercury Intrusion Porosimetry (MIP), usually destructive, is widely used for a correct characterisation of porous materials providing a wide range of study [11]. This method is fundamentally based on the principles of hydrostatic pressure applied to the mechanical behaviour of mercury, where this pressure is attributed to the pore diameter or vacuum, into which a specific volume of mercury penetrates.

There are multiple methodologies that are coupled to different parameters to determine WRC, but it is generally measured using a pressure plate, where, continuously, a pressure is applied to the sample to obtain a certain number of unique data. These values are contrasted with explicit samples, which have important relative humidity levels corresponding to the capillary region of the adsorption isotherm. Another method used consists of a stress plate on which suction is applied with a suspended water column [12], this method using a sample analyzed in the entire low-suction range [13].

To represent this variable and extrinsic and intrinsic soil-dependent behavior, constitutive equations have been developed with precepts already established from the state of the art of the subject. In other words, there is already a path travelled in terms of generating both models and equations that can explain the non-linearity of the soil in an approximate way. That is, the heterogeneity existing in different paths for any geotechnical parameter analyzed; in the stress-strain curve or, in a more reduced 
context, in the relationship of WRC with PaSD.

Most of the equations based in the context of this investigation are based on the assumption that WRC depends on PSD [14]. These assumptions superimpose a relationship of an integrated frequency distribution curve between PaSD, WRC and PSD. It is important to understand how the WRC can explain the water-holding properties of a collapsible porous clay, but because of the complexity involved in determining the most critical properties of unsaturated soils, such as shear strength or hydraulic conductivity [15], geotechnical engineers commonly exhibit hesitation in using these properties in problem solving.

Encouraging the use of computation or geotechnical resolutions in collapsible soils by demonstrating the potential relationship between PaSD, WRC and PSD, underpins the objective of this research paper, supported by empirical tests with current and innovative methodologies, to implement a new state of idealized correlation between the most representative parameters in unsaturated soil mechanics.

In most of the current elastoplastic constitutive models [16] - [18], it is difficult to correctly predict the behavior of soils when the mechanical response is highly influenced by hydraulic hysteresis [19], i.e., when constitutive variables that are not directly related to the degree of saturation are included. This dependence on the parameters of unsaturated soil mechanics leads to the development of approximate idealisations of the heterogeneous distribution of stresses and deformations. This nonlinear disposition potentially infers in the framework of response to the alteration of their mechanical properties.

According to [20], one of the essential parameters in unsaturated flow and infiltration models is water retention in the soil. The measurement of soil suction is therefore a prerequisite for understanding the behavior of unsaturated soils, since many of the models are prescribed in terms of suction and net stress state, i.e., the measurement of stress around the air pressure boundary within the pore.

The WRC was initially the means that could idealize the suction in situ, and also a direct relationship between water content and suction [21]. When a soil sample is subjected to variations in the hydraulic gradient, the WRC values of wetting and drying vary significantly. This infers that the WRC contains not only a much wider range of possible values for the suction, but also provides an estimate of the unsaturated properties [22].

There are still constitutive models that are based on functions that require parameters representing conductivity and effective capillary impulse [23]. The null test assumes constant conditions for any increase in air pressure applied within the pores, which have sufficient continuity of air phase, i.e., this method, using invariant conditions of water mass flow, expresses intrinsic constitutive variables of a type of suction that maintains a directly proportional relationship between pore and air pressure [24]. As a tool for indirect measurement of soil suction, filter paper [25], [26] is usually used. When having low suction values, it is easier to measure the matrix suction than the total suction [27].

Fredlund's cell, used in this article for the WRC tests, measures the water content and the total volumetric change under variations of the axial load. The volume change of the sample is expressed as a function of the vertical movement of the load plate. A variety of factors extrinsic to these methodologies are attributed to the different calibration curves within the literature amalgam [28]. This diversity indicates the need for further research on the correlation of unsaturated soil parameters, since the permeability function for an unsaturated soil is related to the WRC [21].

The stress-strain relationship is potentially affected by variations in the degree of saturation, giving rise to alterations within the elastoplastic constituent context, in addition to including plastic transitions within the suction and isotropic volumetric state of the soil. The relationship between these behaviors damages the water retention capacity, that is, if most of the predictions of the constituent models are based on precepts of independence between total stresses, suction and specific volume [29], an approximate idealization of the behavior of unsaturated soils under critical conditions will not be established.

Several theories have been proposed to correlate permeability with pore size distribution [30], [31]. Studies conducted by [32] show that permeability is a 
direct function of PSD. PSD obtained through mercury intrusion contributes to the interpretation of critical behavioural characteristics of unsaturated soils. [33] studied this methodology by giving it a common framework to provide information on the relationship between WRC and PSD.

The permeability coefficient has commonly depended on the void ratio only, but in an unsaturated soil, it is also a function of water content. According to [34], both void ratio, water content and saturation degree are related in permeability, as well as WRC depends directly on water content and saturation. Under these conditions, a relevant relationship between these constitutive variables can be generated. For unsaturated soils, this coefficient of permeability may present wide intervals of variability, even more so if worked with clays, exhibiting wide uncertainties in soil leaching properties [14].

The graph relating water content and suction is the soilhumidity characteristic curve [35], which can be obtained by mercury intrusion, i.e., if the WRC depends on water content and suction, and these in turn can be formulated in terms of hydrostatic pressure expressed in units of mercury, the bilateral relationship between the WRC and the PSD can be interpreted as directly proportional. As soon as pressure is the inflexible constituent parameter in both the suction and the PSD. Each of the correlations that can be attributed to the variability of the WRC, PSD and PaSD, depend on (1) The effect of hydraulic hysteresis, derived from the geometric heterogeneity of the pores, (2) Saturation and (3) Suction in terms of partial or total pressure with no external loads applied. The hysteresis in the WRC. consists in that a soil during the wetting and drying process has different trajectories, which result in identifying, that for the same suction value, the humidity is higher in the drying curve, than in the wetting one.

PaSD can be presented and used in different ways, dimensionally differentiated to attribute to a particle size a specific curve, defined by arbitrary limits or ranges, that can represent its classification [36]. Details of the use of these curves are widely discussed in the geotechnical literature as in [37]. [22] developed a convenient method to estimate the WRC by means of PaSD.

Numerous investigations are underway to find the relationship between these three constituent parameters.
However, some establish trajectories that build more explanatory models, as is the case of the study carried out by [38], in which, in a practical way, the relationship between WRC and PaSD is established by means of the similarity between their respective curves. In addition to already established constitutive models that outline this co-dependence and relationship between WRC, PSD and $\mathrm{PaSD}$, there are currently functions that describe WRC from the estimation of PSD [39], [40] and [41]. [42] estimated the PSD index by means of the PaSD slope in logarithmic representation.

Recently, the model [43], has identified the similarities of the PaSD curve versus the cumulative particle percentage curve to determine WRC. Therefore, it employs a physical framework that uses the already known relationship between pore diameter (PaSD) and the hydrostatic pressure within the pore (PSD), the latter also described by the capillarity equation; and assumes the relationship between pore diameter and particle diameter to predict WRC behavior.
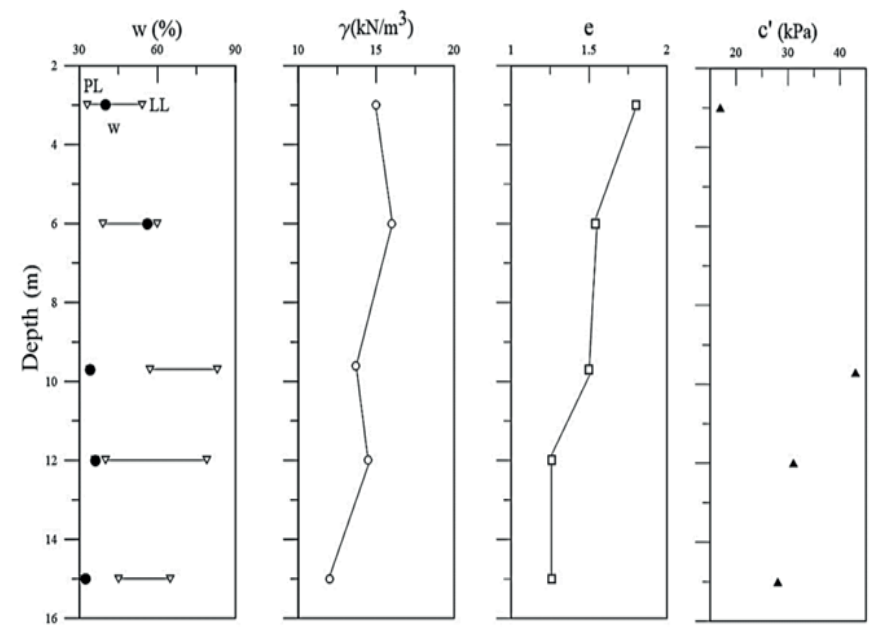

Figure 1. Basic characterization of the material [44]

\section{Materials and Methods}

\section{Basic characterization of the material}

Laboratory tests were conducted to perform a complete characterization of the chemical and physical structure of the Brasilia porous clay presented in Figure 1 and Table 1, which by exhibiting a high void ratio (close to 2 ) and a low unit weight, enhances its collapsible pathology. 
Table I. Physical properties of the soil [45]

\begin{tabular}{|c|c|c|c|c|}
\hline Depth (m) & Gs & LL (\%) & LP (\%) & IP (\%) \\
\hline $3.00-3.25$ & 2.65 & 56.4 & 31.2 & 25.2 \\
\hline $6.00-6.30$ & 2.66 & 59.8 & 34.6 & 25.2 \\
\hline $8.70-9.00$ & 2.66 & 66.8 & 36.4 & 30.4 \\
\hline
\end{tabular}

This classification indicates how changes in particle size, by creating large false particles formed by silt and clay bonds, can generate variability in the distribution curves in the ISP, which exhibits a clear distribution of macro and micropores in the analyzed sample. Microconcretions are excessively recurrent in the cohesive soils of Brasilia-DF, this structuring denotes progressive patterns of collapse in the internal porous structure (Figure 2). To determine bulk density, mercury injection tests were performed within the pores of the in-situ samples. The higher the pressure applied to the intrusion, the smaller the pore size [46].

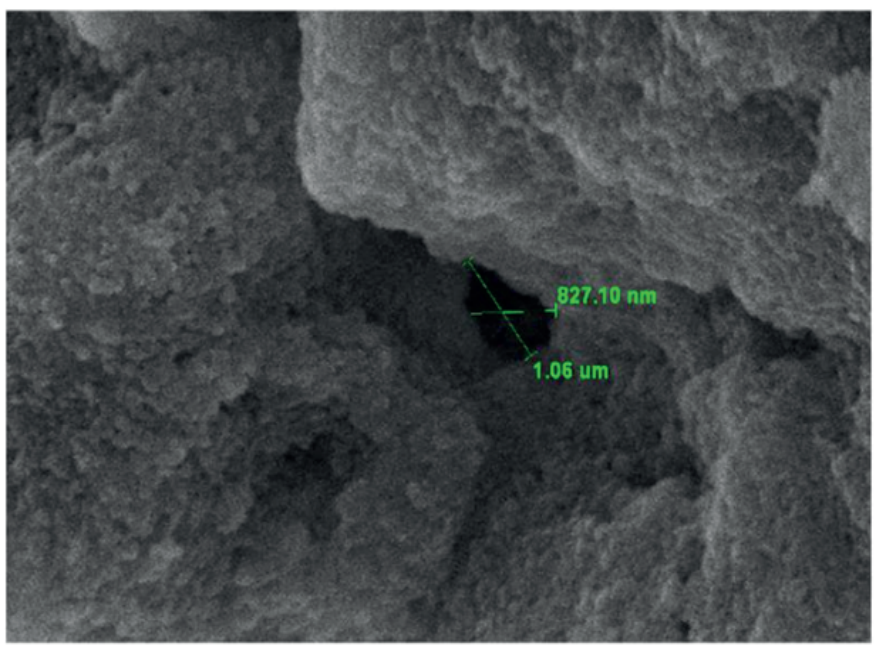

Figure 2. Scanning Electron Microscope image - SEM [45]

The response of tropical soils depends directly on weathering and bimodal granulometric and porosimetric behavior. When changes in the molecular distribution of the material are generated, both the capillary pressures and the hyperbolic tendency of the SWCC curve.

The different current imaging techniques allow a dimensional approach to the behaviour obtained by means of methodologies such as PSD and WRC. These techniques allow the spatial observation of minerals, particle diameter, pore diameter, micropores and, in general, the microstructure of the clay body. In Figure 2, it can be seen that on a scale of $\mu \mathrm{m}$ and $\mathrm{nm}$ it is possible to observe the typical laminar structure for this material.

\section{Specialized tests}

An effective tool for determining PaSD, ISP also provides the ability to discern texture classes and the proportion of materials with a greater than $95 \%$ confidence interval (readings every 10 seconds, for 8 or 24 hours), based on high-precision measurements of gradual pressure series at specific variable depths within a sedimentation tank. The measuring depth is $20 \mathrm{~cm}$. However, the relationship between depth and the various measurement topics can be directly proportional.

With respect to traditional methods, ISP does not require constant monitoring or personnel interference and relies exactly on the rudimentary pipette process, which represents the primal state of PaSD [47]. The comparison of these three methods is illustrated in Figure 3.

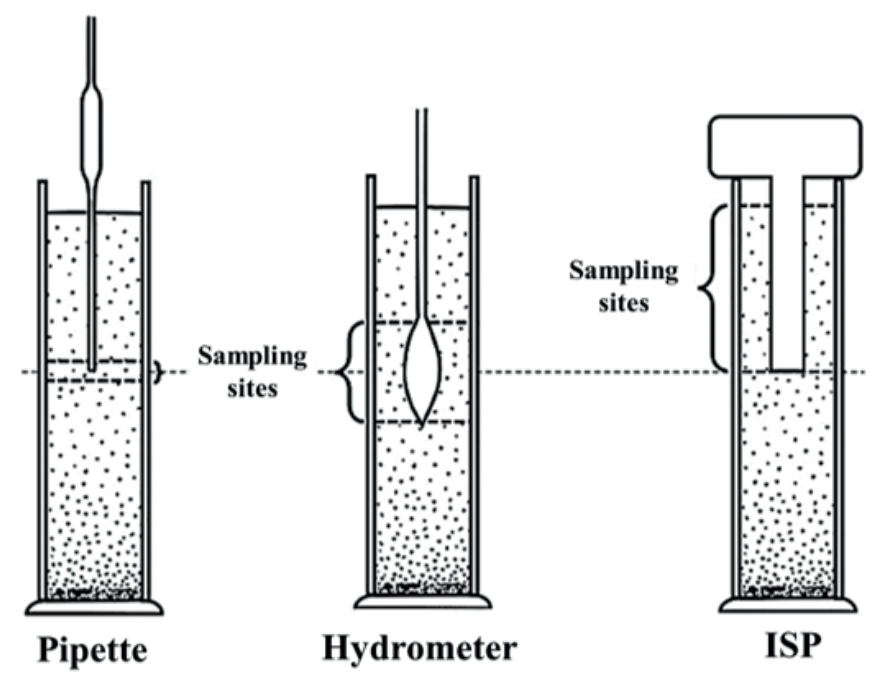

Figure 3. Schematic measurement of PaSD [47]

The water-holding capacity of a soil can be expressed by the plasticity index (PI), which is closely correlated with the WRC. The matrix suction represents the prototype that directly associates water content with WRC, therefore, it is fundamental to understand some soil properties such as shear strength, compressibility and flow.

Fredlund's cell concentrates different characteristics that together can facilitate the process of measuring the suction. The device has the ability to measure the water content of a soil sample without removing any of its accessories during the test. Therefore, the field overload pressure can be simulated by applying vertical loads. When the suction ranges are very small, the WRC can 
be measured by the "hanging column" accessory, which allows the application of low suction to the soil samples. The procedural setup is similar to traditional onedimensional pressure plate extractors. Table II describes the restrictions of the commonly used matrix suction calculation methods compared to the Fredlund cell.

Table II. Matrix suction methods $[2,47,48,49]$

\begin{tabular}{|l|l|l|l|l|}
\hline \multicolumn{1}{|c|}{ Device } & \multicolumn{1}{|c|}{$\begin{array}{c}\text { Method } \\
\text { (Measured } \\
\text { property) }\end{array}$} & $\begin{array}{c}\text { Measured } \\
\text { Suction }\end{array}$ & Range (kPa) & \multicolumn{1}{|c|}{ Restrictions } \\
\hline $\begin{array}{l}\text { Filter paper ASTM } \\
\text { D5298-10(Contact) }\end{array}$ & $\begin{array}{l}\text { Indirect } \\
\text { (Water content) }\end{array}$ & Matrix & Total range & $\begin{array}{l}\text { It is not possible to technify the } \\
\text { procedure }\end{array}$ \\
\hline Pressure plate & Directly from & Matrix & 0 a 1500 & $\begin{array}{l}\text { The suction range is limited by the air } \\
\text { inlet on the plate. }\end{array}$ \\
\hline Suction plate & Directly from & Matrix & 0 a 90 & Low utility range. \\
\hline $\begin{array}{l}\text { Standard } \\
\text { sphygmomanometer }\end{array}$ & Directly from & Matrix & 0 a 90 & $\begin{array}{l}\text { Temperature fluctuations affect } \\
\text { parameter calibration. }\end{array}$ \\
\hline Fredlund & Directly from & Matrix & $>1500$ & $\begin{array}{l}\text { Water absorption when actual suction is } \\
\text { greater than the AEV }\end{array}$ \\
\hline
\end{tabular}

The mercury intrusion method for determining PSD is one of the most common and most widely used methods for porous materials. The method involves measuring the pressure required for the mercury to enter the pores of a dry sample and the volume of mercury used in each intrusion. To correlate the pore diameter with the applied pressure, several constitutive equations have been developed and coupled to models that study the interrelationship of the parameters, through the probability of pore damage as a secondary factor of the method.

The relationship between pore size and applied pressure is inversely proportional. Therefore, since soils are exposed to high pressure variations, they can suffer alterations, mainly in their microstructure. It is important to recognize this phenomenon, since damage to the pore can affect the re-intrusion characteristics and lead to variations in PSD. Although research regarding this pathology is circulating in the literature, there is little or no evidence of these inferences in the changes in pore size after the application of piezometric gradients.

Under increasing absolute pressures, mercury must be subjected to the influence of surface tension as it enters a small pore size, this non-wetting fluid displaces air within the pores and incubates a new interface with the soil (Figure 4).

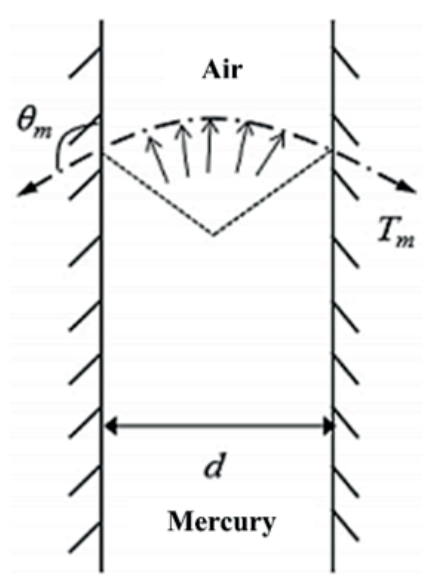

Figure 4. Air-Mercury-Soil Interface [50]

\section{Results and Discussion}

The relationship between PSD and WRC has been demonstrated due to the coherence that exists between their results, understanding that a soil with a bimodal pore size distribution, will reveal some inherited maxima from the basic curve of intruded volume in the material. These peaks in the curve show a close relationship with both micro and macropore VEA, as qualitatively demonstrated [5], in Figure 5.

However, the PaSD obtained from more accurate methods such as ISP, allows for a wider and more precise granulometric curve, as well as a continuous resolution of the PaSD. This confirms the possibility of the existence of a third actor that may present a relationship with PSD and WRC, since the suction acting on a soil is not only controlled by the pore size, but also consequently by the particle size.

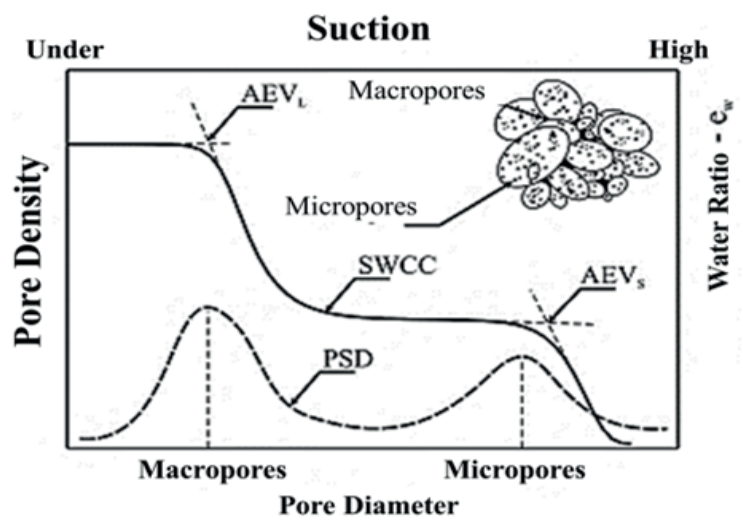

Figure 5. Typical analogy between pore density function and retention curve [5] 
Figure 6 shows the high difference in results obtained by state-of-the-art methods such as PSI and traditional methods such as hydrometer. The curve obtained by hydrometry describes a restricted trajectory with no data for particles larger than $0.03 \mathrm{~mm}$. Similarly, this method does not reveal the presence of particles for values less than $0.09 \mathrm{~mm}$. This shows that the use of techniques based on automated sedimentation measurement ends up being more accurate than traditional measurements.

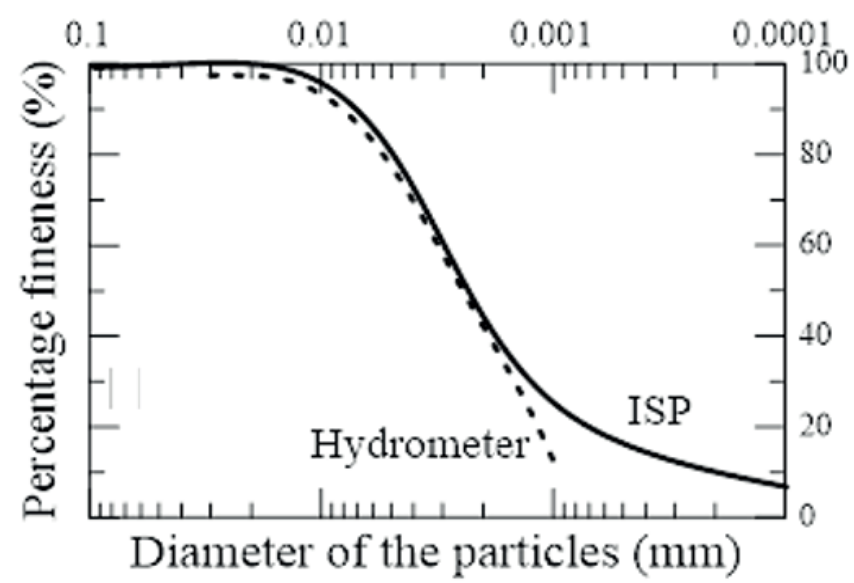

Figure 6. Comparison between traditional and modern methods of obtaining PaSD [authors]

\section{Relationship between PaSD, WRC and PSD}

As already mentioned, the relationship between WRC and PSD has been established in some studies. However, the inclusion of PaSD using precise methodologies has not been studied so far. It is evident that the suction created in the microstructure of the material is not only governed by the size and shape of the pore, but also the particle influences this behaviour. Especially when particle sizes become smaller, i.e. sizes smaller than $0.002 \mathrm{~mm}$, diameters corresponding only to argilomaterials. Figure 7 shows the possible relationship between the pore size distribution (PSD), the particle size distribution (PaSD) and the water retention curve (WRC).

Clearly, for this particular material the interrelationship between the WRC (pressure load vs. volumetric moisture) and the PSD (dV/dlogR vs. pore radius), corresponds to that expected. The turning points of the retention curve that belong to the air inlet values (AEV), both in micropores and macropores, show a correlation, at least graphically or qualitatively, with the maxima of the porosimetry curve. This can be explained physically, because the micropore predominance of this sample must be validated with higher suction values (AEVmicro), as can be seen in the figure.

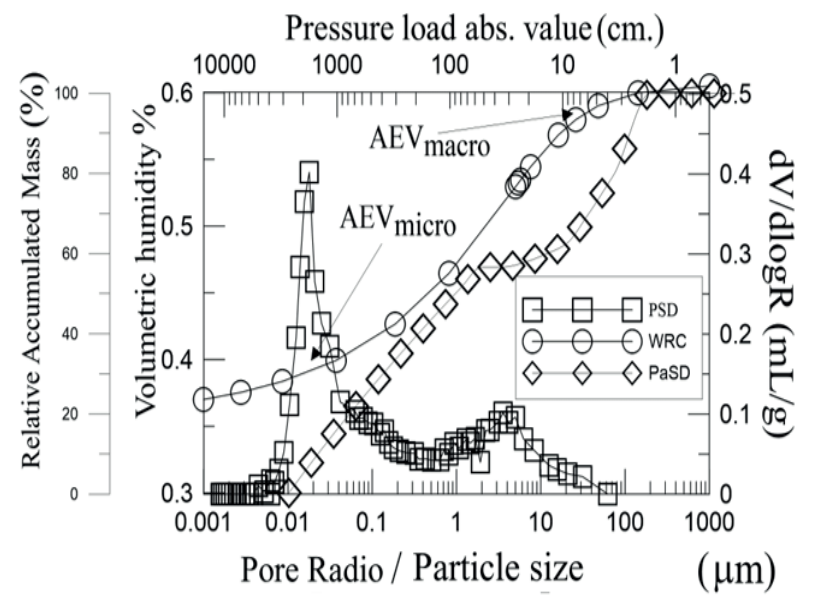

Figure 7. Comparison between traditional and modern methods of obtaining PaSD [authors]

Regarding the inclusion of PaSD (Particle size vs. relative accumulated mass), in the analysis, it is consistent to think that for this type of soil, which has a content of fines greater than $80 \%$, that is, particles smaller than $75 \mathrm{~m}$ and within these approximately $60 \%$ of particles are smaller than $2 \mathrm{~m}$, that is, argilomaterials; the dependence of the unsaturated response is not only considered from the average diameter of the pore, but also from the size of the particles, since the "micro chamber" where the suction is developed in the structure of the soil, is evidently controlled by these two aspects.

\section{Conclusions}

Indeed, a correct characterization of this type of collapsible porous clays, which have a laterite origin, must contain a biased analysis with information from PaSD, PSD and WRC tests. Tropical soils are highly dependent on partial saturation, which in turn depends on factors related to particle size and pore distribution. Modern methods for obtaining particle size distribution are predominant today, since traditional methods are found to have some deficiencies in the results. Also the water retention curve (WRC), ideally should be reproduced by at least two or three methods, due to the uncertainty generated by some missing turning points.

It was shown experimentally that there is a correlation, at least quantitatively, between pore size and particle size 
distributions and the water retention curve. The air inlet values (AEV), both macropore and micropore, which are revealed as turning points in the pressure-loaded versus volumetric humidity space of the WRC, show a connection with the peaks in the $\mathrm{dV} / \mathrm{d} \log \mathrm{R}$ space versus the pore radius of the PSD. As for the interrelationship with the PaSD, this is clearly noticed in the particles smaller than 75 microns, since in the graphs this value is related to the macropore AEV.

\section{Acknowledgements}

The authors are grateful for the support provided by the Vice-Rector's Office for Research at the Universidad Militar Nueva Gravada, for this research. This article is based on the PIC-ING-2858 project.

\section{References}

[1] J. Sánchez-Molina, A. Sarabia-Guarín, y D. C. Álvarez-Rozo, "Evaluación de materias primas utilizadas en la fabricación de baldosas de gres en el sector cerámico de Norte de Santander (Colombia)", Respuestas, vol. 21, no. 2, pp. 48 $-56,2016$.

[2] J. M. Padilla, Y. Perera, W. N. Houston, et al., "A new soil-water characteristic curve device", Proceedings of the advanced experimental unsaturated soil mechanics, EXPERUS, pp. 1522, 005 .

[3] A. Kareem and K. Mahmood, "Nature of SoilWater Characteristics Curves (SWCC) for Soils from Anbar Governorate", Anbar Journal for Engineering Sciences, vol. 3, no. 1, pp. 61-80, 2010.

[4] S. K. Vanapalli and D. G. Fredlund, "Empirical procedures to predict the shear strength of unsaturated soils", In Eleventh Asian Regional Conference on Soil Mechanics and Geotechnical Engineering, Hong et al.(eds.), pp. 93-96, 1999.

[5] I. Otálvaro, "Estudo Teórico-Experimental de Solos Tropicais Compactados: Aplicação a um caso de estabilidade de taludes", Ph.D. thesis, Universidade de Brasília, 2013.

[6] J. Ruge, "Análise do comportamento de cortina de estacas executada em solo poroso metaestável mediante o uso de um modelo constitutivo hipoplástico considerando a resposta não saturad. Brasília", Ph.D. thesis, Universidade de Brasilia, 2014.

[7] A. Jotisankasa, "Collapse behaviour of a compacted silty clay. London: Doctoral dissertation", University of London, 2005.

[8] J. Ashworth, D. Keyes, R. Kirk, et al., "Standard procedure in the hydrometer method for particle size analysis", Communications in Soil Science and Plant Analysis, vol. 32, no. 5-6, pp. 633-642, 2001.

[9] D. Gabriels and D. Lobo, "Métodos para determinar granulometría y densidad aparente del suelo", Venesuelos, vol. 14, no. 1, pp. 37-48, 2011.

[10] P. Berliner, P. Barak and Y. Chen, “An improved procedure for measuring water retention curves at low suction by the hanging-water-column method", Canadian Journal of Soil Science, vol. 60, no. 3, pp. 591-594, 1980.

[11] H. Giesche, "Mercury porosimetry: a general (practical) overview", Particle \& particle systems characterization, vol. 23, no. 1, pp. 9-19, 2006.

[12] L. D. Baver, W.H. Gardner and W. R. Gardner, "Soil physics", New York: John Wiley and Sons Inc, 1973.

[13] J. A. Vomocil, "Porosity Methods of Soil Analysis". Part 1. Physical and Mineralogical Properties, Including Statistics of Measurement and Sampling, (methodsofsoilana), pp. 299-314, 1965.

[14] D. G. Fredlund and A. Xing, "Equations for 
the soil-water characteristic curve", Canadian geotechnical journal, vol. 31, no. 4, pp. 521-532, 1994.

[15] C. Gallage, R. Udukumburage, T. Uchimura, et al., "Comparison of direct and indirect measured soil-water characteristic curves for a silty sand", International Journal of GEOMATE, vol. 13, no. 39, pp. 9-16, 2017.

[16] E. E. Alonso, A. Gens and A. Josa, "A constitutive model for partially saturated soils", Géotechnique, vol. 40, no. 3, pp. 405-430, 1990.

[17] S. J. Wheeler and V. Sivakumar, "An elastoplastic critical state framework for unsaturated soil", Géotechnique, vol. 45. no. 1, pp. 35-53, 2003.

[18] A. Josa, A. Balmaceda, A. Gens, et al., "An elasto-plastic model for partially saturated soils exhibiting a maximum of collapse", 3rd International Conference on Computational Plasticity, vol. 1, pp. 815-826, 1992.

[19] D. Gallipoli, A. Gens, J. Vaunat, et al., "Role of Degree of Saturation on the Normally Consolidated Behaviour of Soils", 3rd International Symposium on Unsaturated Soil (Unsaturated Soils), pp. 115-120, 2002.

[20] W. J. Rawls and D. L. Brakensiek, "Estimation of soil water retention and hydraulic properties", Unsaturated flow in hydrologic modeling, pp. 275-300, 1989.

[21] D. G. Fredlund, "Unsaturated soil mechanics in engineering practice. Hoboken, New Jersey", John Wiley \& Sons, Inc, 2012.

[22] M. D. Fredlund, G. W. Wilson and D. G. Fredlund, "Use of the grain-size distribution for estimation of the soil-water characteristic curve", Canadian Geotechnical Journal, vol. 39, no. 5, pp. 1103-1117, 2002.
[23] D. R. Nielsen, M. Th. van Genuchten and J. W. Biggar, "Water flow and solute transport processes in the unsaturated zone", Water Resources Research, vol. 22, no. 9, pp. 89S-108S, 1986.

[24] R. E. Olson y L. J. Langfelder, "Pore-Water Pressures in Unsaturated Soils", Journal of the Soil Mechanics and Foundations Division, vol. 91, no. SM4, pp. 127-160, 1965.

[25] S. L. Houston, W. N. Houston and A. M. Wagner, "Laboratory filter paper suction measurements", Geotechnical Testing Journal, vol. 17, no. 2, pp. 185-194, 1994.

[26] E. C. Leong, L. He and H. Rahardjo, "Factors affecting the filter paper method for total and matric suction measurements", Geotechnical Testing Journal, vol. 25, no. 3, pp. 322-333, 2002.

[27] R. G. McKeen, "Field studies of airport pavements on expansive clay", In Expansive Soils ASCE, pp. 242-261, 1980.

[28] H. M. Elgabu. "Critical evaluation of some suction measurement techniques. Cardiff", Doctoral dissertation, Cardiff University, 2013.

[29] S. J. Wheeler, R. S. Sharma and M. S. R. Buisson, "Coupling of hydraulic hysteresis and stress-strain behaviour in unsaturated soils", Géotechnique, vol. 53, no. 1, pp. 41-54, 2003.

[30] C. H. Juang and R. D. Holtz, "Fabric, pore size distribution, and permeability of sandy soils", Journal of Geotechnical Engineering, vol. 112, no. 9, pp. 855-868, 1986.

[31] I. Garcia-Bengochea, A. G. Altschaeffl y C. W. Lovell, "Pore distribution and permeability of silty clays", Journal of the Geotechnical Engineering Division, vol. 105, no. 7, pp. 839- 
856, 1979.

[32] C. Lapierre, S. Leroueil and J. Locat, "Mercury intrusion and permeability of Louiseville clay", Canadian Geotechnical Journal, vol. 27, no. 6, pp. 761-773,1990.

[33] E. Romero, A. Gens and A. Lloret, "Water permeability, water retention and microstructure of unsaturated compacted Boom clay", Engineering Geology, vol. 54, no. 1-2, pp. 117$127,1999$.

[34] E. C. Leong and H. Rahardjo, "Permeability functions for unsaturated soils", Journal of geotechnical and geoenvironmental engineering, vol. 123, no. 12, pp. 1118-1126, 1997.

[35] S. Prapaharan, A. G. Altschaeffl and B. J. Dempsey, "Moisture curve of compacted clay: mercury intrusion method", Journal of Geotechnical Engineering, vol. 111, no. 9, pp. 1139-1143, 1985.

[36] G. W. Gee and D. Or, "Particle-size analysis", Methods of soil analysis, vol. 4, no. 598, pp. 255293, 2002.

[37] W. C. Krumbein and F. J. Pettijohn, "Manual of sedimentary petrography" D. Appleton-Century company, incorporated, 1938.

[38] K. R. J. Smettem and P. J. Gregory. "The relation between soil water retention and particle size distribution parameters for some predominantly sandy Western Australian soils", Soil Research, 34(5), 695-708, 1996.

[39] G. S. Campbell. "Soil physics with BASIC: transport models for soil-plant systems". Elsevier, 1985.

[40] W. M. Schuh, R.L. Cline and M.D. Sweeney. "Comparison of a laboratory procedure and a textural model for predicting in situ soil water retention". Soil Science Society of America Journal, vol. 52, no. 5, pp. 1218-1227, 1988.

[41] R.T. Haverkamp and J.Y. Parlange, "Predicting the water-retention curve from particle-size distribution: 1. Sandy soils without organic matter 1", Soil Science, vol. 142, no. 6, pp. 325339, 1986.

[42] K. Smettem, K. Bristow, P. Ross, R. Haverkamp, S. Cook and A. Johnson. "Trends in water balance modelling at field scale using Richards' equation", Trends in Hydrology, vol. 1, pp. 383402, 1994.

[43] L. Arya and J. Paris. "A physicoempirical model to predict the soil moisture characteristic from particle-size distribution and bulk density data 1", Soil Science Society of America Journal, vol. 45, no. 6, pp. 1023-1030, 1981.

[44] J. Ortigao, R. Cunha and L. Alves, "In situ tests in Brasilia porous clay", Canadian Geotechnical Journal, vol. 33, no. 1, pp. 189-198, 1996.

[45] J. Ruge, A. López, F. Molina-Gómez, et al., "Numerical Simulations of K0 Triaxial Tests on Collapsible Porous Clay", Geotechnical Engineering Journal of the SEAGS \& AGSSEA, vol. 49, no. 3, pp. 171-183, 2018.

[46] D. G. Fredlund y H. Rahardjo. Soil mechanics for unsaturated soils. Toronto, Canadá: John Wiley \& Sons, 1993.

[47] A. M. Ridley y W. K. Wray, Suction measurement: a review of current theory and practices, Proceedings of the first international conference on unsaturated soils, vol. 3, September 1995.

[48] J. M. Padilla y Y.Y. Perera, Performance of Fredlund thermal conductivity sensor, Proc., 11th Tailings and Mine Waste Conf, pp. 125-133, October, 2004. 
[49] W. Durner, S. C. Iden y G. von Unold, The integral suspension pressure method (ISP) for precise particle-size analysis by gravitational sedimentation, Water Resources Research, vol. 53, no. 1, pp. 33-48, January 2017.

[50] G. Tao, Y. Chen, H. Xiao, Q. Chen y J. Wan, Determining Soil-Water Characteristic Curves from Mercury Intrusion Porosimeter Test Data Using Fractal Theory, Energies, vol. 12, no. 4, pp. 752, February 2019. 